\title{
ПЕРСПЕКТИВЫ КОМПЛЕКСНОГО ОСВОЕНИЯ БАКЧАРСКОГО ЖЕЛЕЗОРУДНОГО МЕСТОРОЖДЕНИЯ (ЗАПАДНАЯ СИБИРЬ, РОССИЯ)
}

\section{Рудмин Максим Андреевич',} rudminma@tpu.ru

\author{
Мазуров Алексей Карпович', \\ akm@tpu.ru \\ Рева Игорь Витальевич', \\ igor_1993@mail.ru \\ Стеблецов Максим Дмитриевич', \\ boss.steblecov@mail.ru
' Национальный исследовательский Томский политехнический университет, Россия, 634050, г. Томск, пр. Ленина, 30.

\begin{abstract}
Актуальность исследования. Приводится анализ и оценка комплексных ресурсов Бакчарского месторождения, которое до настоящего времени считалось исключительно железорудным месторождением морских оолитовых железняков. Изученные второстепенные минеральные продукты могут быть предметом добычи для первоочередной окупаемости объекта.

Основная цель работы заключалась в качественной и количественной оценке потенциальных попутных минеральных компонентов Бакчарского месторождения.

Использовались следующие аналитические методы: оптическая микроскопия и петрографический анализ, сканирующая электронная микроскопия, рентгенодифракционный анализ, рентгенофлуоресцентный анализ.

В результате проведенных исследований получены следующие основные выводы. Ресурсы глауконита на месторождении составляют около 800 млн т. В пределах западного детально разведанного участка площадью 5 км² ресурсы глауконита оцениваются в 34 млн т при среднем содержании 27,8 \%, из которых 4,6 млн т составляют глауконитолиты, 18,1 млн т - глауконитовые песчаники и 11,3 млн т - глауконит-шамозит-гетитовые ооидовые железняки. Туронские песчанистые алевролиты ипатовской свиты обогащены магнетитом и ильменитом при их суммарном среднем содержании в породе 15,2%. Наличие этих минералов обеспечивает высокий магнитный сигнал (магнитная восприимчивость) отложений: $113,4 . \ldots 295,7 \cdot 10^{-5}$ ед. Си. (первый и второй квартиль, соответственно). Ресурсы магнетита и ильменита по 13 пересечениям в пределах западного участка месторождения составляют около 2,75 млн т. Из этих ресурсов на долю ТіО долю $\mathrm{Fe}_{2} \mathrm{O}_{3}-934,9$ тыс. т (при среднем содержании $\mathrm{Fe}_{2} \mathrm{O}_{3} 34$ \%). Текстурные особенности описанных пород (слабая цементация) позволяют рекомендовать скважинную гидродобычу как метод первоочередной разработки как глауконитовых залежей, так и магнетит-ильменитового пласта.
\end{abstract}

\section{Ключевые слова:}

Попутные компоненты, Бакчарское месторождение, глауконит, магнетит, ильменит, ресурсы, Западная Сибирь.

\section{Введение}

Бакчарское месторождение железа было открыто в 1957 г. поисковой партией Западно-Сибирского управления [1] и уже более 60 -ти лет является предметом научных исследований и геологических споров. Среди них особое внимание заслуживают работы А.А. Бабина, И.В. Николаевой, Н.Х. Белоус, А.Н. Кондакова, М.П. Нагорского, Ю.П. Казанского [1, 2]. В глобальной повестке Бакчарское месторождение - это эталонный объект одного из самых распространённых типов железных руд - осадочных морских месторождений. $\mathrm{K}$ этому же типу относятся такие известные объекты, как Лотарингский бассейн (Франция, Германия, Бельгия и Люксембург), вабановские толщи в Ньюфаундленде (Канада), силурийская Клинтонская группа Центральных и Южных Аппалачей (США), Аятское месторождение (Казахстан), Керченский бассейн (Россия) и пр. Природа колоссального количества железа в осадочных морских месторождениях до сих пор остаётся предметом научных дискуссий
[3-14]. Отличительными особенностями этих месторождений является приуроченность руд к шельфовым фациям эпиконтинентальных морей, оолитовая или ооидовая структура, гетит-шамозит-сидеритовый минеральный состав [15] и высокие общие запасы железа.

Ресурсы железа на Бакчарском месторождении оцениваются в 28 млрд т $[1,16]$. Хотя это только часть гигантского Западно-Сибирского железорудного бассейна, ресурсы которого по оценке ведущих экспертов составляют около 400 млрд т [1]. Однако, несмотря на такие впечатляющие цифры, разработка Бакчарского месторождения является в большей степени мифом, нежели долгосрочной перспективой. Последнее связано со следующими основными проблемами: (1) сложные инженерногеологические условия за счет высокой обводненности вмещающих и вскрышных пород при низкой стоимости товарной руды, (2) относительно низкие технологические показатели, связанные с невысоким содержание железа и повышенным содержа- 
нием фосфора как вредной примеси, (3) отсутствие рентабельной технологии обогащения руды.

В данной работе приводится доказательство того, что Бакчарское месторождение является в определенной степени комплексным объектом и заключает в себе перспективные попутные компоненты, которые могут быть предметом первоочередной добычи. Этот тезис распространяется как на другие объекты Западно-Сибирского бассейна (Колпашевское, Парабельское, Ласкинское, Елогуйское, Нижне-Байховское, Туруханское рудопроявления), так и на месторождения-аналоги других бассейнов. Цель работы заключалась в качественной и количественной оценке потенииальных попутных линеральных колпонентов Бакчарского месторождения.

\section{Объект исследования}

Бакчарское месторождение железа находится в юго-восточной части Западной Сибири (52 $01^{\prime} 45^{\prime \prime} \mathrm{C}$; $82^{\circ} 07^{\prime} 20^{\prime \prime}$ ) в 200 км от г. Томск на северо-запад (рис. $1, a)$. Это наиболее изученный объект Западно-Сибирского железорудного бассейна, который представляет собой широкую полосу (шириной около 150 км) осадочных образований верхнемелового и палеогенового возраста, протягивающуюся почти на 2000 км вдоль восточного и юго-восточного обрамления Западно-Сибирской плиты.

Железные руды месторождения залегают на глубине от 157 до 230 м среди пород верхнемелового и палеогенового возраста [1, 2, 17-21]. Рудоносная толща Бакчарского месторождения представляет собой трансгрессивный комплекс морских прибрежных и мелководных отложений мощностью около 80 м (рис. $2, a)$, локализованный в платформенном чехле Западно-Сибирской плиты. Месторождение приурочено к северной оконечности куполообразной структуры мезозоя, называемой Бакчарским погребенным валом [1]. К северо-западу и востоку от оси водораздела рек Галка и Бакчар прослеживается пологое погружение рудных горизонтов. В западной части месторождения кровля верхнего (бакчарского) рудного горизонта залегает на глубине $157 . . .160$ м от дневной поверхности, тогда как в восточной части на глубине $170 . .175$ м от дневной поверхности.

Оолитовые железные руды месторождения концентрируются в трех основных рудоносных горизонтах (рис. $1, b$ ): нарымском, колпашевском и бакчарском $[1,2]$. Нарымский горизонт приурочен к кровле ипатовской свиты (коньяк, верхний мел), которая перекрывает морские глины и мелкозернистые песчаники кузнецовской свиты (сеноман, верхний мел). Ипатовская свита представляет собой мелкозернистые песчаники, серовато-зеленые алевролиты с прослоями глин, которые переходят вверх по разрезу в оолитовые железняки. Колпашевский горизонт залегает среди славгородской (сантон-кампан, верхний мел) и ганькинской (маастрихт, верхний мел) свит, которые сложены глауконитовыми песчаниками, алевролитами и алевритистыми глинами. Бакчарский горизонт локализован в подошве люлинворской свиты (ранний палеоген). Нижняя часть люлинворской свиты представлена среднезернистыми песками и песчаниками с толщей оолитовых железняков, которые перекрываются серыми параллельно слоистыми глинами в верхней части свиты. (a)

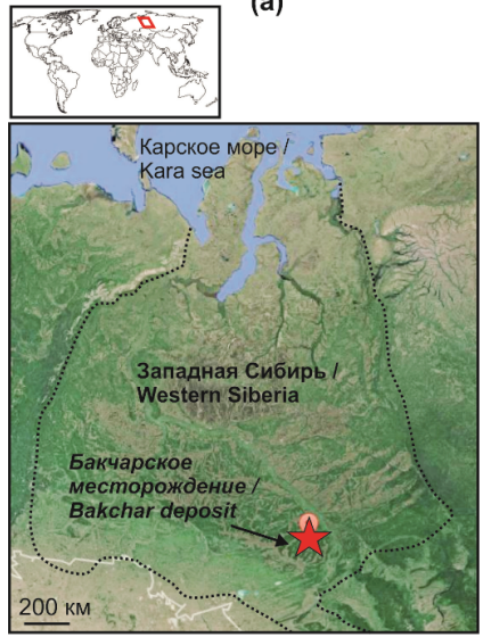

(b)

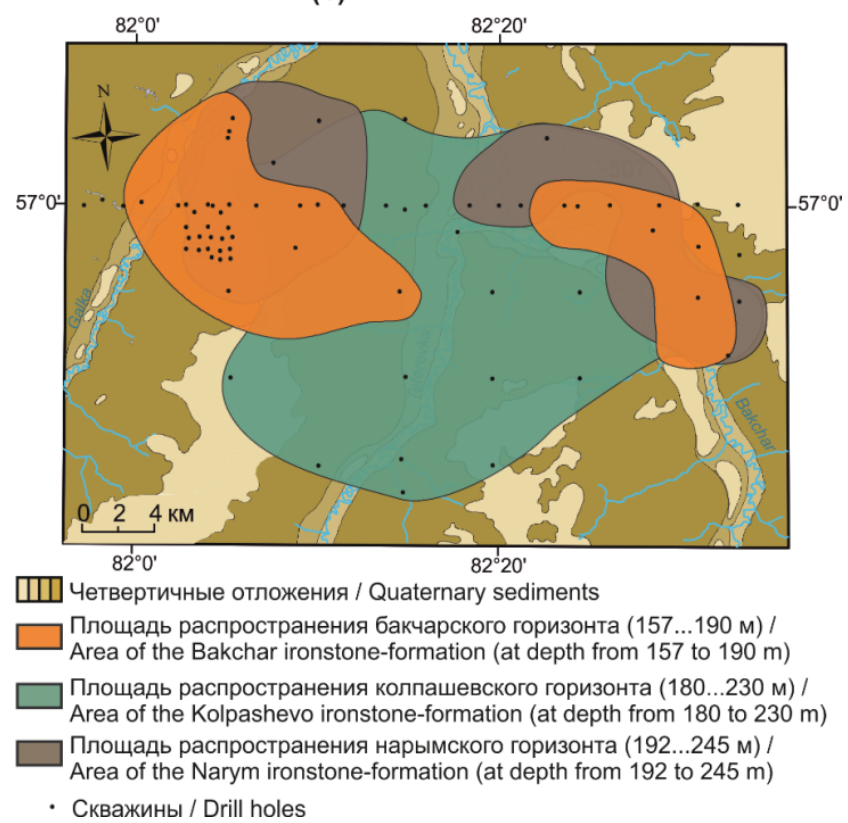

Pис. 1. Обзорная карта (Google Earth) расположения Бакчарского месторождения (а) и схематическая геологическая карта с проекцией железоносных горизонтов на дневную поверхность (b)

Fig. 1. Location map (Google Earth image) of Bakchar deposit (a) and simplified geological map of the Bakchar deposit with distribution of three main ironstone-formations (b) 
Известия Томского политехнического университета. Инжиниринг георесурсов. 2018. Т. 329. № 10. 85-94

(a)

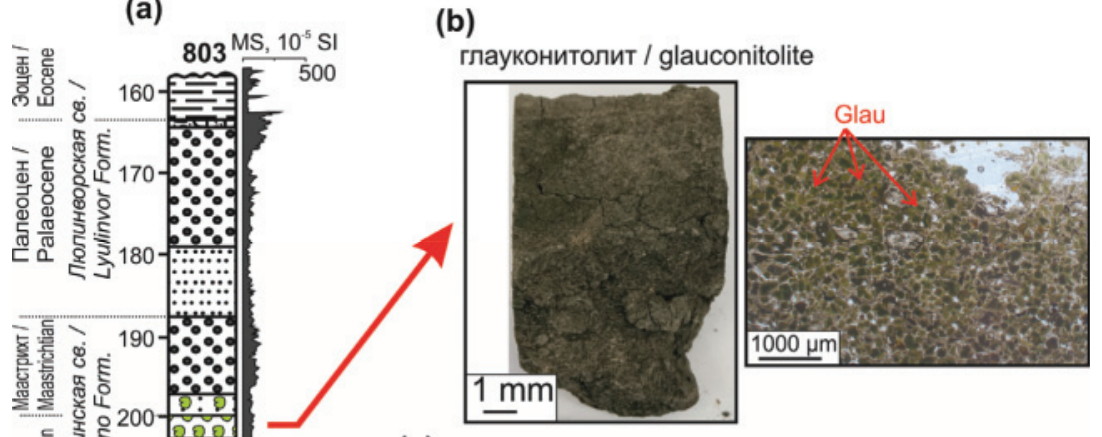

(c)

песчанистый алевролит / sandy siltstone Mgt $\mathrm{\| m}$

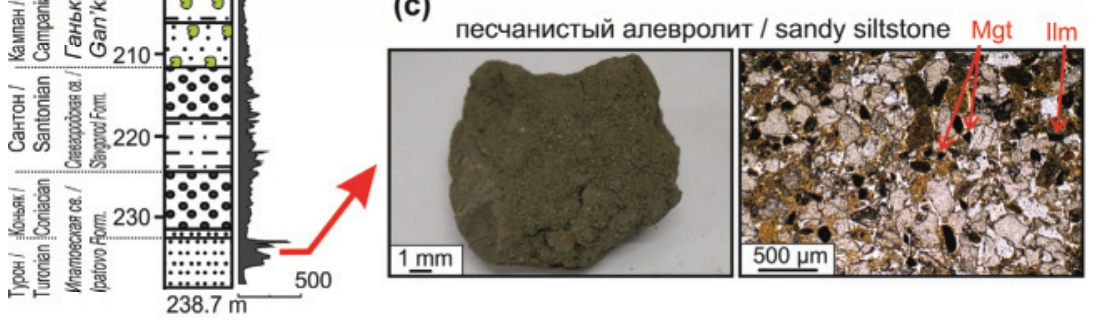

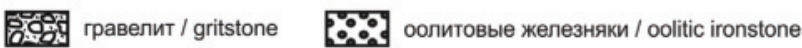

::::::- песчаник/sandstone छणg глауконитолит / glauconilite

$\because-$ -

E-7 глины / claystone

Glau - глауконит / glauconite

Mgt - магнетит / magnetite

Ilm - ильменит / ilmenite

Pис. 2. Схематическая стратиграфическая колонка Бакчарского месторождения с вертикальным профилем магнитной восприимчивости (a), фотографии изучаемых пород со снимками в проходящем свете: глауконитолита (b) и туронских песчанистых алевролитов (c)

Fig. 2. Stratigraphic columns of Bakchar deposit with magnetic susceptibility profile (a), photos of studied rocks with images of petrographic thin sections (transmitted light): glauconitolite (b) and turonian sandy siltstone (c)

\section{Материал и методика исследования}

Для лабораторных исследований использовались 53 репрезентативные пробы, отобранные из керна скважин Бакчарского месторождения. Пробы соответствовали двум основным типам изучаемых пород: 40 проб глауконитсодержащих пород и 13 проб туронских песчанистых алевролитов.

Минералогический анализ выполнялся по следующей методике: первичное описание на оптическом микроскопе, дробление исходной породы, отмучивание в дистиллированной воде, гранулометрическое просеивания мокрым способом, электромагнитная сепарация (ЭВС 10/5), дочистка и выделение мономинеральных фракций под бинокуляром. Петрографические исследования полированных шлифов осуществлялись на микроскопе (ZEISS Axio Imager.A2m). Рентгенодифракционный анализ (РДА) производился на рентгеновском дифрактометре Bruker D2 Phaser c $\mathrm{CuK}_{\alpha}$ излучением. Истертые до размера менее $10 \mu \mathrm{m}$ препараты сканировались в интервале углов $2 \theta 3 . . .70^{\circ}$ с шагом $0,02^{\circ}$, скоростью сканирования 1 с, при параметрах измерения 40 кВ и 40 мА. Рентгенофлуоресцентный анализ (РФА) как метод реализации силикатного анализа выполнялся с использованием микроанализатора HORIBA X-Ray Analytical Microscope XGT 7200, оснащенного энергодисперсионным детектором с пределом обнаружения химических элементов до 0,01\%. Анализ производился на подготовленных препаратах (таблетках) при паpaметрах: напряжение $50 \mathrm{\kappa B}$, сила тока 0,5 мА, время сканирования 100 с, площадь сканирующего луча 1,2 мм. Таблетки изготавливались следующим образом: истертая проба спрессовывалась под гидравлическим прессом, после чего спекалась в муфельной печи в течение 9 часов при температуре $900{ }^{\circ} \mathrm{C}$. Потери при прокаливании (ППК) определялись как разница между исходным весом и весом после прокаливания пробы в муфельной печи при $900{ }^{\circ} \mathrm{C}$. Сканирующая электронная микроскопия (СЭМ) проводилась с использованием микроскопа TESCAN VEGA 3 SBU, оснащенного приставкой для рентгенофлуоресцентного энергодисперсионного анализа (ЭДС) OXFORD X-Max 50 с Si/Li кристаллическим детектором. Ускоряющее напряжение для СЭМ съемки и анализа было 20 кВ с интенсивностью тока зонда в пределах 4...12,2 нА. Для изучения морфологии минеральные зерна прикреплялись на предметное стекло при помощи двухстороннего углеродного скотча и исследовались в режиме низкого вакуума с применение LVSTD (Low Vacuum Secondary Tescan Detector) детектоpa. Рентгеноспектральный анализ производился на полированных шашках, представляющих собой скопление минеральных зёрен в эпоксидной смоле и покрытых тонким слоем углерода (30 нм). Оценка ресурсов выполнялась методом среднего арифметического с использованием ПО Micromine. Ин- 
терполяция содержания полезного компонента в контуре рудных тел осуществлялась методом обратных расстояний.

\section{Результаты}

Глауконитовые породы

Глауконит широко распространён среди верхнемеловой осадочной последовательности Бакчарского месторождения [22], и в отложениях ганькинской и славгородской свит его содержания достигают 60 \% [23, 24]. В предыдущих работах авторами были опубликованы данные с детальной структурно-вещественной характеристикой этих пород [23-26], а также результаты практического их использования. Глауконит - это глинистый минерал из группы диоктаэдрических слюд типа 2:1 (Т: 0: Т) с десицитом межслоя, который характеризуется высоким содержанием калия (до 8 \%) и отличается зеленой окраской и глобулярной формой [27-31]. Минерал, как правило, формируется в прибрежно-морских фациях [27-30, 32, 33], что объясняет его преобладание в разрезе месторождения. Глауконит обладает рядом полезных свойств, что делает его предметом разнопланового практического использования [34-39], однако наибольший интерес к нему проявляется как к нетрадиционному типу минерального удобрения [40-44].

Глауконитсодержащие породы Бакчарского месторождения подразделяются на глауконитолиты (рис. $2, b$ ), глауконитовые песчаники/алевролиты, глауконит-шамозит гетитовые ооидовые железняки (последние слагают колпашевский рудный горизонт) [23]. Авторами было выявлено, что глауконит Бакчарского месторождения можно использовать как: (i) собственно калийное минеральное удобрение [23, 25], (ii) источник калийной соли при использовании технологии обжига и выщелачивания [45], (iii) сорбционный материал для извлечения тяжелых металлов из водных растворов [46].

Общие ресурсы глауконита Бакчарского месторождения из славгородской и ганькинской свит оцениваются почти в 800 млн т при средней мощно- сти 4 м, среднем содержании глауконита 24,3\% и среднем объемном весе пород 2,3 т/ $\mathrm{m}^{3}$. При этом в пределах западного участка Бакчарского месторождения площадью $5 \mathrm{kм}^{2}$ ресурсы глауконита оцениваются в 34 млн т при среднем содержании 27,8 \% (рис. 3). Из них 4,6 млн т составляют глауконитолиты, 18,1 млн т - глауконитовые песчаники и 11,3 млн т - глауконит-шамозит-гетитовые ооидовые железняки. Пласт глауконитолитов имеет мощность до 8 м при среднем содержании глауконита $59 \%$ и залегает на глубинах $198 . .210$ м. Пласт глауконитовых песчаников характеризуется мощностью до 12 м, средним содержанием глауконита 33,3 \% и глубиной залегания $205 . .225$ м. Пласт глауконит-шамозит-гетитовых железняков прослеживается на глубинах $180 \ldots 190$ м и имеет среднее содержание глауконита 18,6 \% .

При таких ресурсах месторождения можно считать крупнейшей сырьевой базой для производства калийных минеральных удобрений на основе глауконита, а также материалов для создания других инновационных продуктов. Использование этих пород может способствовать обеспечению сельскохозяйственных потребителей сибирских регионов экологически безопасным и эффективным калийным удобрением местного производства. Глауконитолиты - это наиболее богатые по содержанию глобулярного глауконита породы, что позволяет использовать их в качестве минеральной добавки в сельскохозяйственные почвы без предварительного обогащения. Применение же простейших методов отмучивания и электромагнитной сепарации позволяет выделять из этих пород чистейший глауконитовый концентрат с содержанием глауконита до 97 \% [23]. Глауконитовые песчаники/алевролиты и глауконит-шамозит-гетитовые ооидовые железняки могут быть использованы для получения глауконитового концентрата с содержанием глауконита до 70 \% по схеме «мокрое» просеивание и электромагнитная сепарация [23]. Глауконитовые концентраты являются продуктом разнопланового практического использования.

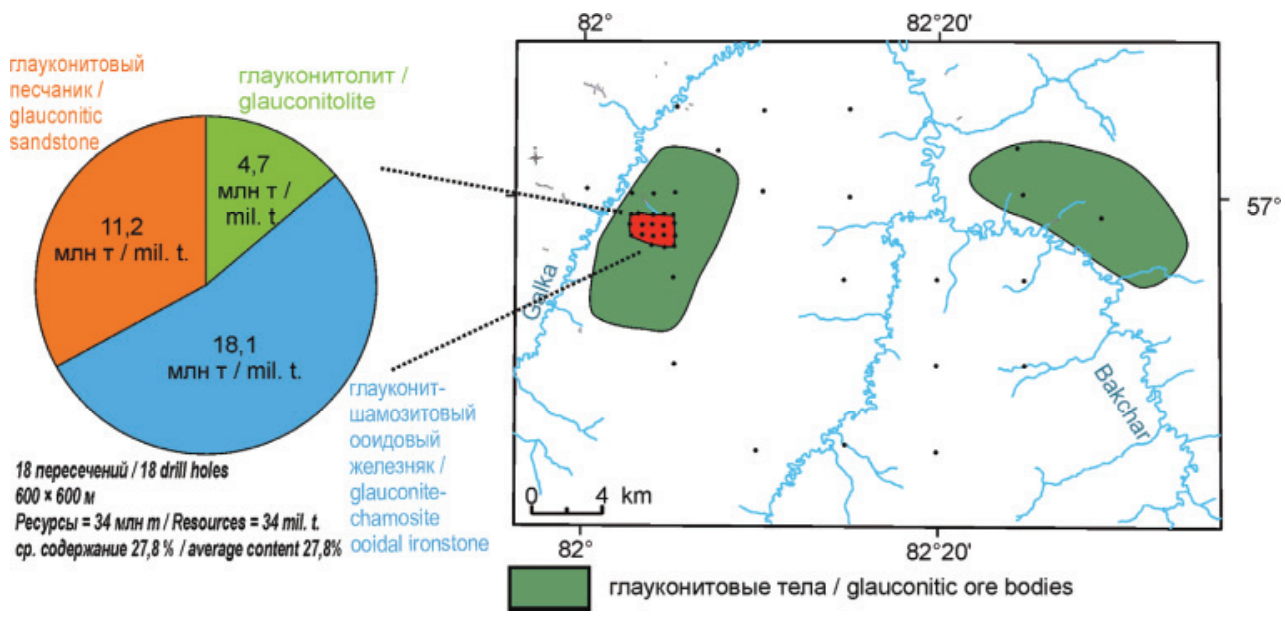

Рис. 3. Схема распространения глауконитовых залежей Бакчарского месторождения

Fig. 3. Scheme of distribution of glauconitic ore bodies within the Bakchar deposit 
В агрохозяйстве их можно использовать как самостоятельное минеральное удобрение и/или как источник калийных солей [45]. Глауконитовые концентраты возможно использовать как материал для разработки водоочистных фильтров [47-51] или защитные минеральные покрытия при рекультивации производственных площадок и захоронении бытовых отходов [52, 53].

\section{Туронский магнетит-ильменитовые отложения}

Песчанистые алевролиты туронского возраста приурочены к подошве ипатовской свиты и залегают ниже нарымского горизонта. Эти отложения отличаются в разрезе месторождения аномально высоким значением магнитной восприимчивости (рис. 2, a). Магнитная восприимчивость (MS) этих пород изменяется в пределах $113,4 . . .295,7 \cdot 10^{-5}$ ед. Си. (первый и второй квартиль, соответственно), что выделяет эти породы из разреза месторождения, MS которого изменяется в пределах $35,9 \ldots 85,5 \cdot 10^{-5}$ ед. Си. (первый и второй квартиль, соответственно). Это темно-серые, иногда со слабым зеленоватым оттенком слабосцементированные песчанистые алевролиты. Среднее процентное содержание фракции $(-0,5+0,16)$ мм в них составляет $18,2 \%$, фракции $(-0,16+0,04) \mathrm{Mм}-50,1 \%,(-0,04)$ мм $-14,8 \%$. Песчаники состоят из обломков кварца, полевых шпатов, древесных органических остатков и тяжелых акцессорных минералов. Среди акцессорных минералов преобладают следующие: ильменит, магнетит (рис. $4, a$ ), гематит, а также отмечается циркон, монацит. Среднее содержание магнитных минералов в изучаемых породах составляет 15,2 \% . По данным рентгенодифракционного анализа магнитной фракции пород содержание магнетита составляет 40,3\%, ильменита - 37,6 \% .

Магнетит в туронских породах месторождения присутствует в виде кристаллов октаэдрической формы либо в виде обломков неправильной формы. Октаэдрические кристаллы имеют гладкие грани с ровными ребрами, иногда отмечается ступенчатая структура (рис. $4, b, c$ ). Размер кристаллов относительно выдержан и составляет менее 100 мкм в диаметре. Размеры обломков магнетита, как правило, изменяются в более широких пределах - от десятков до 400 мкм. Относительно крупные обломки иногда имеют субоктаэдрическую форму с округлыми очертаниями (рис. $4, d$ ). На поверхности зёрен часто наблюдаются следы коррозии в виде ямочек и каверн, как произвольной формы, так и по направлениям кристаллографических плоскостей (рис. $4, c$ ). Размеры обломков неправильной формы изменяются от 200 до 400 мкм. Редко встречаются срастания кристаллов магнетита с кварцем, еще реже с монацитом. Ильменит встречается в виде небольших таблитчатых кристаллов и обломков неправильной формы, размеры которых не превышают 200 мкм. Неправильная форма зёрен, окатанность и следы коррозии свидетельствуют о терригенной природе магнетита и ильменита в туронских отложениях.
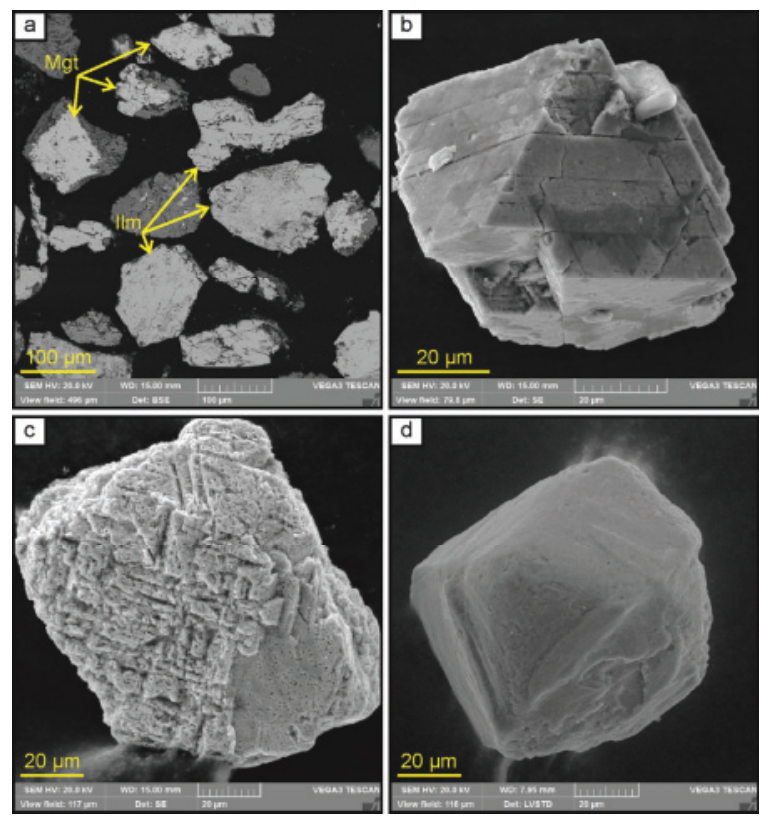

Pис. 4. (а) Магнетит (Mgt) и ильменит (IIm) в полированном аншлифе, (b) магнетит октаэдрического габитуса с кристаллическими зонами роста, (c) следы коррозии на поверхности зерна магнетита, (d) зерно магнетита субоктаэдрического габитуса

Fig. 4. (a) Magnetite (Mgt) and ilmenite (IIm) in a polished thin section, (b) magnetite of the octahedral habit with crystalline growth zones, (c) traces of corrosion on the surface of the magnetite grains, (d) magnetite grains of suboctahedral form

Химический состав магнетита по данным рентгеноспектрального анализа характеризуется содержанием $\mathrm{Fe}_{2} \mathrm{O}_{3(\text { (общ) }}$ от 90 до $98 \%, \mathrm{TiO}_{2} 0,3 . .5,3 \%$; $\mathrm{V}_{2} \mathrm{O}_{5}$ 0,3...0,4\%. Состав ильменита описывается содержанием $\mathrm{TiO}_{2} 46 . .58 \%$ и $\mathrm{Fe}_{2} \mathrm{O}_{3 \text { (обш) }} 37 . . .48 \%$, с примесью $\mathrm{MnO}$ до $5 \%$.

Ресурсы магнетита и ильменита по 13 пересечениям в пределах западного участка месторождения около с. Бакчар (площадь $3 \mathrm{~km}^{2}$ ) составляют около 2,75 млн т при среднем содержание магнитных минералов в пределах пласта 15,2 \% , средней мощности 4,5 м и объемной массе породы 2,3 т/ $\mathrm{M}^{3}$. При этом на долю $\mathrm{TiO}_{2}$ приходится около 815 тыс. т (при среднем содержании $\mathrm{TiO}_{2}-29,6 \%$ ), а на долю $\mathrm{Fe}_{2} \mathrm{O}_{3(\text { общ) }}-934,9$ тыс. т (при среднем содержании $\mathrm{Fe}_{2} \mathrm{O}_{\text {3(общ) }}-34$ \%). Слабая цементация пород позволяют рассматривать скважинную гидродобычу как приемлемый метод разработки магнетит-ильменитового пласта.

\section{Выводы}

В результате проведенных комплексных исследований вмещающих пород Бакчарского месторождения были получены следующие основные выводы.

1. Ресурсы глауконита на месторождении составляют около 800 млн т. В пределах западного детально разведанного участка площадью $5 \mathrm{kм}^{2}$ ресурсы глауконита оцениваются в 34 млн т при среднем содержании $27,8 \%$, из 
которых 4,6 млн т составляют глауконитолиты, 18,1 млн т - глауконитовые песчаники и 11,3 млн т - глауконит-шамозит-гетитовые ооидовые железняки.

2. Туронские песчанистые алевролиты ипатовской свиты обогащены магнетитом и ильменитом при их среднем содержании в породе $15,2 \%$. Наличие этих минералов обеспечивает высокий магнитных сигнал (магнитная восприимчивость) отложений: $113,4 . .295,7 \cdot 10^{-5}$ ед. Си. (первый и второй квартиль, соответственно). Ресурсы магнетита и ильменита по 13 пересечениям в пределах западного участка месторождения составляют около 2,75 млн т. Из этих ресурсов на долю $\mathrm{TiO}_{2}$ приходится около 815 тыс. т (при среднем содержании $\mathrm{TiO}_{2}-29,6 \%$ ), а на долю $\mathrm{Fe}_{2} \mathrm{O}_{3(\text { (общ) }}-934,9$ тыс. т (при среднем содержании $\mathrm{Fe}_{2} \mathrm{O}_{3(\text { (об) }}-34 \%$ ).

3. Текстурные особенности описанных пород (слабая цементация) позволяют рекомендовать скважинную гидродобычу как метод первоочередной разработки как глауконитовых залежей, так и магнетит-ильменитового пласта.

Работа выполнена при финансовой поддержке РФФИ и Администрации Томской области (грант 16-45-700090) и гранта РФФИ (18-35-00022). Обработка материала осуществлялась при поддержке Правительства РФ (контракт № 14.Z50.31.0012).

\section{СПИСОК ЛИТЕРАТУРЫ}

1. Западно-Сибирский железорудный бассейн. - Новосибирск: CO PAH CCCP, 1964. - $448 \mathrm{c}$.

2. Николаева И.В. Бакчарское месторождение оолитовых железных руд / под ред. А.Л. Яншина. - Новосибирск: Наука, 1967. $-134 \mathrm{c}$.

3. Afify A.M., Sanz-Montero M.E., Calvo J.P. Differentiation of ironstone types by using rare earth elements and yttrium geochemistry - a case study from the Bahariya region, Egypt // Ore Geology Reviews. - 2018. - V. 96. - P. 247-261.

4. Van Houten F.B., Bhattacharyya D.P. Phanerozoic Oolitic Ironstones - Geologic Record and Facies Model // Annual Review of Earth and Planetary Sciences. - 1982. - V. 10 (1). - P. 441-457.

5. Kimberley M.M. Debate about ironstone: has solute supply been surficial weathering, hydrothermal convection, or exhalation of deep fluids? // Terra Nova. - 1994. - V. 6 (2). - P. 116-132.

6. Sturesson U. Lower Palaeozoic iron oolites and volcanism from a Baltoscandian perspective // Sedimentary Geology. - 2003. V. 159 (3-4). - P. 241-256.

7. Petranek J., Van Houten F.B. Phanerozoic ooidal ironstones // Czech Geological Survey Special Papers. - 1997. - V. 7. P. 4-71.

8. Maynard J.B. Geochemistry of oolitic iron ores, an electron microprobe study // Economic Geology. - 1986. - V. 81 (6). P. $1473-1483$.

9. Young T.P. Phanerozoic ironstones: an introduction and review // Geological Society Special Publication. - 1989. - V. 46. P. 9-25.

10. Kholodov V.N., Nedumov R.I., Golubovskaya E.V. Facies types of sedimentary iron ore deposits and their geochemical features: Communication 2. Problems of the geochemistry of phanerozoic iron ores // Lithology and Mineral Resources. - 2013. - V. 48 (1). P. $14-47$.

11. Conjunction of ore- and oil-forming systems in sedimentary basins and the prediction of ore deposits / D.I. Pavlov, D.I. Gorzhevskiy, G.A. Goleva, M.K. Kalinko, A.A. Kartsev, A.V. Lipayeva // International Geology Review. - 1991. V. 33 (8). - P. 822-829.

12. Mücke A. Part II. Postdiagenetic Ferruginization of Phanerozoic (oolitic) Ironstones: a Contribution to their Geneses // Developments in Sedimentology. - 1994. - V. 51. - P. 396-423.

13. Pavlov D.I. Relationship of sedimentary iron and manganese deposits with petroleum and gas-bearing basins // Geology of Ore Deposits. - 1989. - V. 31. - P. 80-91.

14. Kimberley M.M. Exhalative origins of iron formations // Ore Geology Reviews. - 1989. - V. 5 (1-2). - P. 13-145.

15. Rudmin M.A., Mazurov A.K. Oolitic ores in the Bakchar iron-ore cluster (Tomsk Oblast) // Doklady Earth Sciences. - 2016. V. 471 (2). - P. 1238-1241.

16. Мазуров А.К., Боярко Г.Ю., Емешев В.Г., Комаров А.В. Перспективы освоения Бакчарского железорудного месторождения, Томская область // Руды и металлы. - 2006. - V. 2. P. 64-70.

17. Podobina V.M., Kseneva T.G. Upper Cretaceous zonal stratigraphy of the West Siberian Plain based on foraminifera // Cretaceous Research. - 2005. - V. 26 (1). - P. 133-143.

18. Podobina V.M. Substantiation of the Paleocene-Eocene boundary in western Siberia by foraminifers / Stratigraphy and Geological Correlation. - 1998. - V. 6 (2). - P. 142-149.

19. Stratigraphy of Upper Cretaceous and Cenozoic deposits of the Bakchar iron ore deposit (southwestern Siberia): New data N.K. Lebedeva, O.B. Kuzmina, E.S. Sobolev, I.V. Khazina // Stratigraphy and Geological Correlation. - 2017. - V. 25 (1). P. $76-98$

20. Paleontological and magnetostratigraphic data on Upper Cretaceous deposits from borehole no. 8 (Russkaya Polyana District, Southwestern Siberia) / N.K. Lebedeva, G.N. Aleksandrova, B.N. Shurygin, M.N. Ovechkina, Z.N. Gnibidenko // Stratigraphy and Geological Correlation. - 2013. - V. 21 (1). - P. 48-78.

21. Gnibidenko Z.N., Lebedeva N.K., Levicheva A.V. Magnetostratigraphy of the Campanian -Maastrichtian Bakchar Basin (southeastern West Siberia) // Russian Geology and Geophysics. 2015. - V. 56 (11). - P. 1652-1661.

22. Николаева И.В. Минералогия и геохимия глауконита. - Новосибирск: СО РАН СССР, 1981. - 121 с.

23. Economic potential of glauconitic rocks in Bakchar deposit (S-E Western Siberia) for alternate potash fertilizer / M. Rudmin, S. Banerjee, A. Mazurov, B. Makarov, D. Martemyanov // Applied Clay Science. - 2017. - V. 150. - P. 225-233.

24. Rudmin M., Banerjee S., Mazurov A. Compositional variation of glauconites in Upper Cretaceous-Paleogene sedimentary iron-ore deposits in South-eastern Western Siberia // Sedimentary Geology. -2017 . - V. 355. - P. 20-30.

25. 0 возможности использования в сельском хозяйстве глауконита из пород Бакчарского месторождения (Западная Сибирь) / М.А. Рудмин, А.К. Мазуров, Б.И. Макаров, А.В. Галиханов, М.Д. Стеблецов, К.К. Чепала // Известия Томского политехнического университета. Инжиниринг георесурсов. - 2016. V. 327. - № 11. - P. 6-16.

26. Рудмин М.А., Мазуров А.К., Рева И.В. Минеральные микровключения в глауконитах Бакчарского месторождения (Томская область) // Известия Томского политехнического университета. Инжиниринг георесурсов. - 2016. - V. 327. - № 5. P. 54-64.

27. Odin G.S., Matter A. De glauconiarum origine // Sedimentology. - 1981. - V. 28. - P. 611-641.

28. McRae S.G. Glauconite // Earth-Science Reviews. - 1972. V. 8 (4). - P. $397-440$. 
29. Nature of the structural and crystal-chemical heterogeneity of the Mg-rich glauconite (Riphean, Anabar Uplift) / V.A. Drits, T.A. Ivanovskaya, B.A. Sakharov, B.B. Zvyagina, A. Derkowski, N.V. Gor'kova, E.V. Pokrovskaya, A.T. Savichev, T.S. Zaitseva // Lithology and Mineral Resources. - 2010. - V. 45 (6). P. $555-576$.

30. Amorosi A. Detecting compositional, spatial, and temporal attributes of glaucony: a tool for provenance research // Sedimentary Geology. - 1997. - V. 109 (1-2). - P. 135-153.

31. Summary of recommendations of nomenclature committees relevant to clay mineralogy: Report of the Association International pour l'Etude des Argiles (AIPEA) Nomenclature Committee for 2006 (Clays and Clay Minerals) / S. Guggenheim, J.M. Adams, D.C. Bain, F. Bergaya, M.F. Brigatti, V.A. Drits, M.L.L. Formoso, E. Galan, T. Kogure, H. Stanjek // Clays and Clay Minerals. 2007. - V. 55 (6). - P. 761-772.

32. Banerjee S., Bansal U., Thorat A.V. A review on palaeogeographic implications and temporal variation in glaucony composition // Journal of Palaeogeography. - 2016. - V. 5 (1). - P. 43-71.

33. Compositional variability of glauconites within the Upper Cretaceous Karai Shale Formation, Cauvery Basin, India: Implications for evaluation of stratigraphic condensation / S. Banerjee, U. Bansal, K. Pande, S.S. Meena // Sedimentary Geology. 2016. - V. 331. - P. 12-29.

34. Alternative potassium source for the cultivation of ornamental sunflower / S.T.S. Torqueti, K.V.F. Boldrin, Â.M.P. do Nascimento, P.D.O. Paiva, A.E. Furtini Neto, I.C.A. Luz // Ciencia e Agrotecnologia. - 2016. - V. 40 (3). - P. 257-264.

35. Calculation of the dynamic sorbent capacity in the presence of two sorbates / V.I. Vigdorovich, L.E. Tsygankova, M.N. Esina, A.A. Uryadnikov, N.V. Shel // Journal of Water Process Engineering. - 2017. - V. 20. - P. 180-186.

36. Sorption of heavy metals by Lithuanian glauconite / E.H. Smith, W. Lu, T. Vengris, R. Binkiene // Water Research. - 1996. V. 30 (12). - P. 2883-2892.

37. Characterization and mineral beneficiation of Egyptian glauconite for possible industrial use / S.S. Ibrahim, A.M. El Kammar, A.M. Guda, T.R. Boulos, A. Saleh // Particulate Science and Technology. - 2018. - P. 1-10.

38. The economic potential of El-Gedida glauconite deposits, ElBahariya Oasis, Western Desert, Egypt / G. El-Habaak, M. Askalany, M. Faraghaly, M. Abdel-Hakeem // Journal of African Earth Sciences. - 2016. - V. 120. - P. 186-197.

39. The timing of oceanic anoxic events in the Cretaceous succession of Cauvery Basin: Constraints from ${ }^{40} \mathrm{Ar} /{ }^{39} \mathrm{Ar}$ ages of glauconite in the Karai Shale Formation / U. Bansal, K. Pande, S. Banerjee, R. Nagendra, K.C. Jagadeesan // Geological Journal. - 2018. P. $1-18$

40. Castro L., Tourn S. Direct Application of Phosphate Rocks and Glauconite as Alternative Sources of Fertilizer in Argentina // Exploration and Mining Geology. - 2003. - V. 12 (1-4). - P. 71-78.

41. Franzosi C., Castro L.N., Celeda A.M. Technical Evaluation of Glauconies as Alternative Potassium Fertilizer from the Salamanca Formation, Patagonia, Southwest Argentina // Natural Resources Research. - 2014. - V. 23 (3). - P. 311-320.
42. The potential of glauconitic sandstone as a potassium fertilizer for olive plants / E. Karimi, A. Abdolzadeh, H.R. Sadeghipour, A. Aminei // Archives of Agronomy and Soil Science. - 2012. V. 58 (9). - P. 983-993.

43. Physico-chemical treatment of glauconitic sandstone to recover potash and magnetite / S. Shekhar, D. Mishra, A. Agrawal, K.K. Sahu // Journal of Cleaner Production. - 2017. - V. 147. P. 681-693.

44. Physical and chemical characterization and recovery of potash fertilizer from glauconitic clay for agricultural application / S. Shekhar, D. Mishra, A. Agrawal, K.K. Sahu // Applied Clay Science. - 2017. - V. 143. - P. 50-56.

45. Roasting-leaching experiments on glauconitic rocks of Bakchar ironstone deposit (Western Siberia) for evaluation their fertilizer potential / M. Rudmin, Y. Oskina, S. Banerjee, A. Mazurov, B. Soktoev, M. Shaldybin // Applied Clay Science. - 2018. V. 162. - P. 121-128.

46. Исследование сорбционных свойств образцов глауконита при извлечении ими ионов $\mathrm{Zn}^{2+}, \mathrm{Cd}^{2+}$ и $\mathrm{Cu}^{2+}$ из водных сред / Д.В. Мартемьянов, М.А. Рудмин, Д.А. Кухарь, Ф.Е. Сапрыкин, А.М. Слепнёв, С.О. Казанцев, И.В. Мартемьянова // Теоретические и практические проблемы развития современной науки: сборник материалов 15-й международной научно-практической конференции. - Махачкала: НИЦ Апробация, 2017. - P. 12-13.

47. The study of selectivity of caesium sorption by a natural and surface-modified glauconite in presence of potassium and ammonium ions / V.S. Semenishchev, V.G. Ryabukhina, A.V. Voronina, M.A. Mashkovtsev, A.F. Nikiforov // Journal of Radioanalytical and Nuclear Chemistry. - 2015. - V. 309 (2). - P. 583-588.

48. The removal of uranium and thorium from their aqueous solutions via glauconite / O. Ali, H.H. Osman, S.A. Sayed, M.E.H. Shalabi // Desalination and Water Treatment. - 2015. V. 53 (3). - P. 760-767.

49. Spoljaric N., Crawford W.A. Glauconitic greensand: a possible filter of heavy metal cations from polluted waters / Environmental Geology. - 1978. - V. 2 (4). - P. 215-221.

50. Production and structural-sorption properties of alumosilicates with a hard structural cell modified with polyelectrolyte / M.Y. Trifonova, Y.I. Tarasevich, S.V. Bondarenko, A.I. Zhukov, Z.G. Ivanova // Journal of Water Chemistry and Technology. 2009. - V. 31 (3). - P. 149-155.

51. Franus M., Bandura L. Sorption of heavy metal ions from aqueous solution by glauconite // Fresenius Environmental Bulletin. 2014. - V. 23 (3A). - P. 825-839.

52. Returning land contaminated as a result of radiation accidents to farming use / A.V. Voronina, M.O. Blinova, V.S. Semenishchev, D.K. Gupta // Journal of Environmental Radioactivity. - 2015. V. 144. - P. 103-112.

53. Expediency of the use of natural sorbents for mutagenicity removal from liquid fluorine-organic waste products of monomer FC-141 manufacture / O.M. Revega, H.M. Fitel, S. Bodnarl, Y.B. Kozub // Cytology and Genetics. - 2005. - V. 39 (1). - P. 34-40.

Поступила 30.07.2018.

\section{Информация об авторах}

Рудмин M.A., кандидат геолого-минералогических наук, доцент отделения геологии Инженерной школы природных ресурсов Национального исследовательского Томского политехнического университета.

Мазуров A.K., доктор геолого-минералогических наук, профессор отделения геологии Инженерной школы природных ресурсов Национального исследовательского Томского политехнического университета.

Рева И.В., аспирант Инженерной школы природных ресурсов Национального исследовательского Томского политехнического университета.

Стеблецов М.Д., студент Инженерной школы природных ресурсов Национального исследовательского Томского политехнического университета. 


\title{
PROSPECTS OF INTEGRATED DEVELOPMENT OF BAKCHAR IRON DEPOSIT (WESTERN SIBERIA, RUSSIA)
}

\author{
Maxim A. Rudmin',
} rudminma@tpu.ru

\author{
Aleksey K. Mazurov', \\ akm@tpu.ru \\ Igor V. Reva', \\ igor_1993@mail.ru \\ Maxim D. Stebletsov', \\ boss.steblecov@mail.ru
National Research Tomsk Polytechnic University, 30, Lenin Avenue, Tomsk, 634050, Russia.

\begin{abstract}
The relevance of the research. The authors have analyzed and estimated complex resources of the Bakchar deposit. Until now Bakchar deposit has been considered exclusively as a marine oolitic iron deposit. The studied rocks can be the subject of future mining for the first-priority payback of the facility.

The main aim of the work was the qualitative and quantitative evaluation of the potential associated mineral components of the Bakchar deposit.

The methods: optical microscopy, petrographic analysis, scanning electron microscopy, $X$-ray diffraction, $X$-ray fluorescence analysis. Results. Due to the studies the authors have concluded that glauconite resources for the deposit are about 800 million tons. Resources are estimated at 34 million tons within western detail explored area $\left(5 \mathrm{~km}^{2}\right)$ of deposit with an average glauconite content of $27,8 \%$ (glauconitolite - 4,6 million tons, glauconitic sandstone - 18,1 million tons, glauconite-chamosite-goethite ooidal iron ore - 11,3 million tons). Turonian sandy siltstones of the Ipatovo Formation are enriched with magnetite and ilmenite with their total average content in the rock of $15,2 \%$. The presence of these minerals provides a high magnetic signal (magnetic susceptibility) of sediments of $113,4 \ldots 295,7 \cdot 10^{-5} \mathrm{SI}$ (the first and second quartiles, respectively). The resources of magnetite and ilmenite are about 2,75 million tons within the western area of deposit according to 13 drill holes. $\mathrm{TiO}_{2}$ amounts about 815 thousand tons (with an average $\mathrm{TiO}_{2}$ content of 29,6 \%), and $\mathrm{Fe}_{2} \mathrm{O}_{3}-934,9$ thousand tons (with an average $\mathrm{Fe}_{2} \mathrm{O}_{3}$ content of $34 \%$ ) of these resources. Textural features of the studied rocks (low cementation) allow us to recommend hydraulic borehole mining as a method of priority exploitation of both glauconite deposits and magnetite-ilmenite layer.
\end{abstract}

Key words:

Associated components, Bakchar deposit, glauconite, magnetite, ilmenite, resources, Western Siberia.

This study was supported by the Russian Foundation of Basic Research and Administration of Tomsk region (project 16-45-700090), grant RFBR 18-35-00022 and the Russian Government (no. 14.Z50.31.0012).

\section{REFERENCES}

1. Zapadno-Sibirsky zhelezorudny basseyn [West Siberian iron ore basin]. Ed. by F.N. Shakhova. Novosibirsk, S0 RAN SSSR Publ., 1964. $448 \mathrm{p}$.

2. Nikolaeva I.V. Bakcharskoe mestorozhdenie oolitovykh zhelez nykh rud [Bakchar deposit of oolitic iron ore]. Novosibirsk, S0 AN SSSR, 1967. $129 \mathrm{p}$.

3. Afify A.M., Sanz-Montero M.E., Calvo J.P. Differentiation of ironstone types by using rare earth elements and yttrium geochemistry - a case study from the Bahariya region, Egypt. Ore Geology Reviews, 2018, vol. 96, pp. 247-261.

4. Van Houten F.B., Bhattacharyya D.P. Phanerozoic Oolitic Ironstones - Geologic Record and Facies Model. Annual Review of Earth and Planetary Sciences, 1982, vol. 10 (1), pp. 441-457.

5. Kimberley M.M. Debate about ironstone: has solute supply been surficial weathering, hydrothermal convection, or exhalation of deep fluids? Terra Nova, 1994, vol. 6 (2), pp. 116-132.

6. Sturesson U. Lower Palaeozoic iron oolites and volcanism from a Baltoscandian perspective. Sedimentary Geology, 2003, vol. 159 (3-4), pp. 241-256.

7. Petranek J., Van Houten F.B. Phanerozoic ooidal ironstones. Czech Geological Survey Special Papers, 1997, vol. 7, pp. 4-71.
8. Maynard J.B. Geochemistry of oolitic iron ores, an electron microprobe study. Economic Geology, 1986, vol. 81 (6), pp. 1473-1483.

9. Young T.P. Phanerozoic ironstones: an introduction and review. Geological Society Special Publication, 1989, vol. 46, pp. 9-25.

10. Kholodov V.N., Nedumov R.I., Golubovskaya E.V. Facies types of sedimentary iron ore deposits and their geochemical features: Communication 2. Problems of the geochemistry of phanerozoic iron ores. Lithology and Mineral Resources, 2013, vol. 48 (1), pp. 14-47.

11. Pavlov D.I. Conjunction of ore- and oil-forming systems in sedimentary basins and the prediction of ore deposits. International Geology Review, 1991, vol. 33 (8), pp. 822-829.

12. Mücke A. Part II. Postdiagenetic Ferruginization of Phanerozoic (oolitic) Ironstones: a Contribution to their Geneses. Developments in Sedimentology, 1994, vol. 51, pp. 396-423.

13. Pavlov D.I. Relationship of sedimentary iron and manganese deposits with petroleum and gas-bearing basins. Geology of Ore Deposits, 1989 , vol. 31 , pp. 80-91.

14. Kimberley M.M. Exhalative origins of iron formations. Ore Geology Reviews, 1989, vol. 5 (1-2), pp. 13-145.

15. Rudmin M.A., Mazurov A.K. Oolitic ores in the Bakchar iron-ore cluster (Tomsk Oblast). Doklady Earth Sciences, 2016, vol. 471 (2), pp. 1238-1241. 
16. Mazurov A.K. Perspektivy osvoeniya Bakcharskogo zhelezorudnogo mestorozhdeniya, Tomskaya oblast [Prospects for development of the Bakchar iron ore deposit, Tomsk region]. Rudy i metally, 2006, vol. 2, pp. 64-70.

17. Podobina V.M., Kseneva T.G. Upper Cretaceous zonal stratigraphy of the West Siberian Plain based on foraminifera. Cretaceous Research, 2005, vol. 26 (1), pp. 133-143.

18. Podobina V.M. Substantiation of the Paleocene-Eocene boundary in western Siberia by foraminifers. Stratigraphy and Geological Correlation, 1998, vol. 6 (2), pp. 142-149.

19. Lebedeva N.K. Stratigraphy of Upper Cretaceous and Cenozoic deposits of the Bakchar iron ore deposit (southwestern Siberia): New data. Stratigraphy and Geological Correlation, 2017, vol. 25(1), pp. 76-98.

20. Lebedeva N.K. Paleontological and magnetostratigraphic data on Upper Cretaceous deposits from borehole no. 8 (Russkaya Polyana District, Southwestern Siberia). Stratigraphy and Geological Correlation, 2013, vol. 21 (1), pp. 48-78.

21. Gnibidenko Z.N., Lebedeva N.K., Levicheva A.V. Magnetostratigraphy of the Campanian -Maastrichtian Bakchar Basin (southeastern West Siberia). Russian Geology and Geophysics, 2015, vol. 56 (11), pp. 1652-1661.

22. Nikolaeva I. Mineralogiya i geokhimiya glaukonita [Mineralogy and geochemistry of glauconite]. Novosibirsk, S0 RAS USSSR Press, 1981. $121 \mathrm{p}$.

23. Rudmin M. Economic potential of glauconitic rocks in Bakchar deposit (S-E Western Siberia) for alternate potash fertilizer. Applied Clay Science, 2017, vol. 150, pp. 225-233.

24. Rudmin M., Banerjee S., Mazurov A. Compositional variation of glauconites in Upper Cretaceous-Paleogene sedimentary iron-ore deposits in South-eastern Western Siberia. Sedimentary Geology, 2017, vol. 355, pp. 20-30.

25. Rudmin M.A. On possibility of using Glauconite from rocks of Bakchar deposit (Western Siberia) in agriculture. Bulletin of the Tomsk Polytechnic University. Geo Assets Engineering, 2016, vol. 327 , no. 11, pp. 6-16. In Rus.

26. Rudmin M.A., Mazurov A.K., Reva I.V. Mineral microinclusions in glauconite of Bakchar deposit (Tomsk region). Bulletin of the Tomsk Polytechnic University. Geo Assets Engineering, 2016, vol. 327, no. 5. pp. 54-64. In Rus.

27. Odin G.S., Matter A. De glauconiarum origine. Sedimentology, 1981, vol. 28, pp. 611-641.

28. McRae S.G. Glauconite. Earth-Science Reviews, 1972, vol. 8 (4), pp. 397-440.

29. Drits V.A. Nature of the structural and crystal-chemical heterogeneity of the Mg-rich glauconite (Riphean, Anabar Uplift). Lithology and Mineral Resources, 2010, vol. 45 (6), pp. 555-576.

30. Amorosi A. Detecting compositional, spatial, and temporal attributes of glaucony: a tool for provenance research. Sedimentary Geology, 1997, vol. 109 (1-2), pp. 135-153.

31. Guggenheim S. Summary of recommendations of nomenclature committees relevant to clay mineralogy: Report of the Association International pour l'Etude des Argiles (AIPEA) Nomenclature Committee for 2006 (Clays and Clay Minerals). Clays and Clay Minerals, 2007, vol. 55 (6), pp. 761-772.

32. Banerjee S., Bansal U., Thorat A.V. A review on palaeogeographic implications and temporal variation in glaucony composition. Journal of Palaeogeography, 2016, vol. 5 (1), pp. 43-71.

33. Banerjee S. Compositional variability of glauconites within the Upper Cretaceous Karai Shale Formation, Cauvery Basin, India: Implications for evaluation of stratigraphic condensation. Sedimentary Geology, 2016, vol. 331, pp. 12-29.

34. Torqueti S.T.S. Alternative potassium source for the cultivation of ornamental sunflower. Ciencia e Agrotecnologia, 2016, vol. 40 (3), pp. $257-264$.

35. Vigdorovich V.I. Calculation of the dynamic sorbent capacity in the presence of two sorbates. Journal of Water Process Engineering, 2017, vol. 20, pp. 180-186.
36. Smith E.H. Sorption of heavy metals by Lithuanian glauconite. Water Research, 1996, vol. 30 (12), pp. 2883-2892.

37. Ibrahim S.S. Characterization and mineral beneficiation of Egyptian glauconite for possible industrial use. Particulate Science and Technology, 2018, pp. 1-10.

38. El-Habaak G. The economic potential of El-Gedida glauconite deposits, El-Bahariya Oasis, Western Desert, Egypt. Journal of African Earth Sciences, 2016, vol. 120, pp. 186-197.

39. Bansal U. The timing of oceanic anoxic events in the Cretaceous succession of Cauvery Basin: Constraints from ${ }^{40} \mathrm{Ar} /{ }^{39} \mathrm{Ar}$ ages of glauconite in the Karai Shale Formation. Geological Journal, 2018, pp. 1-18.

40. Castro L., Tourn S. Direct Application of Phosphate Rocks and Glauconite as Alternative Sources of Fertilizer in Argentina. Exploration and Mining Geology, 2003, vol. 12 (1-4), pp. 71-78.

41. Franzosi C., Castro L.N., Celeda A.M. Technical Evaluation of Glauconies as Alternative Potassium Fertilizer from the Salamanca Formation, Patagonia, Southwest Argentina. Natural Resources Research, 2014, vol. 23 (3), pp. 311-320.

42. Karimi E. The potential of glauconitic sandstone as a potassium fertilizer for olive plants. Archives of Agronomy and Soil Science, 2012, vol. 58 (9), pp. 983-993.

43. Shekhar S. Physico-chemical treatment of glauconitic sandstone to recover potash and magnetite. Journal of Cleaner Production, 2017, vol. 147, pp. 681-693.

44. Shekhar S. Physical and chemical characterization and recovery of potash fertilizer from glauconitic clay for agricultural application. Applied Clay Science, 2017, vol. 143, pp. 50-56.

45. Rudmin M. Roasting-leaching experiments on glauconitic rocks of Bakchar ironstone deposit (Western Siberia) for evaluation their fertilizer potential. Applied Clay Science, 2018, vol. 162, pp. 121-128.

46. Martemyanov D.V. Issledovanie sorbtsionnykh svoystv obraztsov glaukonita pri izvlechenii imi ionov $\mathrm{Zn}^{2+}, \mathrm{Cd}^{2+}$ i Cu${ }^{2+}$ iz vodnykh sred [Investigation of the sorption properties of glauconite samples when they extract $\mathrm{Zn}^{2+}, \mathrm{Cd}^{2+}$ and $\mathrm{Cu}^{2+}$ ions from aqueous solutions]. Teoreticheskie i prakticheskie problemy razvitiya souremennoy nauki: sbornik materialov 15 mezhdunarodnoy nauchnoprakticheskoy konferentsii [Theoretical and practical problems of the modern science development. Proc. of the $15^{\text {th }}$ International scientific and practical conference]. Makhachkala, SIC Approbation, 2017. pp. 12-13.

47. Semenishchev V.S. The study of selectivity of caesium sorption by a natural and surface-modified glauconite in presence of potassium and ammonium ions. Journal of Radioanalytical and Nuclear Chemistry, 2015, vol. 309 (2), pp. 583-588.

48. Ali 0 . The removal of uranium and thorium from their aqueous solutions via glauconite. Desalination and Water Treatment, 2015, vol. 53 (3), pp. 760-767.

49. Spoljaric N., Crawford W.A. Glauconitic greensand: a possible filter of heavy metal cations from polluted waters. Environmental Geology, 1978. vol. 2 (4), pp. 215-221.

50. Trifonova M.Y. Production and structural-sorption properties of alumosilicates with a hard structural cell modified with polyelectrolyte. Journal of Water Chemistry and Technology, 2009, vol. 31 (3), pp. 149-155.

51. Franus M., Bandura L. Sorption of heavy metal ions from aqueous solution by glauconite. Fresenius Environmental Bulletin, 2014, vol. 23 (3A), pp. 825-839.

52. Voronina A.V. Returning land contaminated as a result of radiation accidents to farming use. Journal of Environmental Radioactivity, 2015, vol. 144, pp. 103-112.

53. Revega 0.M. Expediency of the use of natural sorbents for mutagenicity removal from liquid fluorine-organic waste products of monomer FC-141 manufacture. Cytology and Genetics, 2005, vol. 39 (1), pp. 34-40. 


\section{Information about the authors}

Maxim A. Rudmin, Cand. Sc., associate professor, National Research Tomsk Polytechnic University.

Aleksey K. Mazurov, Dr. Sc., professor, National Research Tomsk Polytechnic University.

Igor V. Reva, postgraduate, National Research Tomsk Polytechnic University.

Maxim D. Stebletsov, student, National Research Tomsk Polytechnic University. 